\title{
Histopathological Correlation of Squamous Cell Abnormalities Detected on Cervical Cytology
}

\section{Servikal Sitolojide Skuamöz Hücre Anormallikleri Saptanan Olgularda Histopatolojik Korelasyon}

\author{
Remzi ABALI', Besim Haluk BACANAKGíㄹ , Serdar ÇELIK², Özlem ARAS², Pelin KOCA², Birtan BORAN², \\ Nevra DURSUN ${ }^{3}$
}

'Department of Obstetrics and Gynaecology Namık Kemal University, Faculty of Medicine, TEKIRDAĞ, TURKEY, Department of ${ }^{2}$ Obstetrics and Gynaecology and ${ }^{3}$ Department of Pathology, M.H. Istanbul Education and Research Hospital, iSTANBUL, TURKEY

\begin{abstract}
Objective: To investigate the correlation between cytology and cervical biopsy in patients with squamous cell abnormality on cervical cytology.

Material and Method: The cervical smears diagnosed in our clinic between 2005-2008 were reviewed retrospectively. Cases which exhibited squamous cell abnormality (n: 374$)$ were evaluated.

Results: The mean age was $45.15 \pm 10.78$. In the cytopathological results, 256 (68.4\%) ASC-US, 21 (5.6\%) ASC-H, 31 (8.2\%) LSIL, 48 $(12.8 \%) \mathrm{HSIL}$, and $8(4.8 \%)$ invasive carcinomas were diagnosed. Histopathological results were 213 (57\%) nonneoplastic, $85(22.7 \%)$ CIN I, 14 (3.7\%) CIN II, 34(9.0\%) CIN III and 28 (7.5\%) invasive squamous cell carcinomas. Including all squamous cell abnormalities, the sensitivity of the smear test in CIN I and higher grade lesions was $56.95 \%$ and the false positivity was $43.04 \%$. Excluding ASC-US and ASC-H lesions, the sensitivity of the smear test was $77.31 \%$ and the false positivity was $22.68 \%$. After evaluating cervical cytohistopathological correlation, the positive predictive value was found to be $100 \%$ in invasive carcinoma, $62 \%$ in HSIL and $38 \%$ in LSIL.
\end{abstract}

Conclusion: As the grade of cytopathological result increases, the correlation between biopsy and the smear test also increases. The high sensitivity of the cervical smear test for high-grade lesions shows that it is an effective screening test.

Key Words: Cytology, Cervical smears, Papanicolaou test, Pathology
Received : 26.03 .2010

Accepted : 05.02.2011

\section{ÖZ}

Amaç: Servikal sitolojide skuamöz hücre anormallikleri saptanan olguların servikal biyopsi sonuçları ile korelasyonunu araştırmak.

Gereç ve Yöntem: İstanbul Eğitim ve Araştırma Hastanesinde 2005-2008 yılları arasında incelenen servikovaginal yayma sonuçları geriye dönük olarak incelendi. Skuamöz hücre anormallikleri saptanan ve kolposkopik muayene ile servikal biyopsi uygulanan 374 olgu değerlendirmeye alındı.

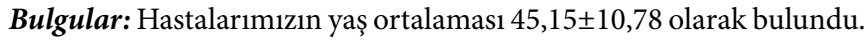
Sitopatolojik inceleme sonuçlarında $256(\% 68,4)$ ASC-US, $21(\% 5,6)$ ASC-H, $31(\% 8,2)$ LSIL, $48(\% 12,8)$ HSIL, $18(\% 4,8)$ invaziv karsinom saptanmıştı. $\mathrm{Bu}$ olguların histopatolojik incelemeleri sonucunda 213 olgu (\%57) nonneoplastik, 85 (\%22,7) CIN I, 14 (\%3,7) CIN II, 34(\%9,0) CIN III, $28(\% 7,5)$ invaziv skuamöz hücreli karsinom tanısı aldı. Skuamöz hücre anormalliklerinin tamamı dahil edildiğinde yayma testinin CIN I ve daha yüksek dereceli lezyonlar için duyarlılığ $\% 56,95$, yanlış pozitifliği \%43,04 bulundu. ASC-US ve ASC-H dışlandığında ise yayma testinin duyarlılığı $\% 77,31$, yanlış pozitifliğini $\% 22,68$ saptadık. Sito-histopatoloji korelasyonu değerlendirildiğinde, pozitif öngörüsel değer en fazla invaziv karsinomda (\%100), sonra sırası ile HSIL (\%62) ve LSIL 'de (\%38) saptandı.

Sonuç: Servikal lezyonların derecesi arttıkça sitoloji-histoloji uyumu artmaktadır. Daha ciddi lezyonlar için servikal yayma testinin duyarlılığının yüksek olması etkin bir tarama testi olduğunu göstermektedir.

Anahtar Sözcükler: Sitoloji, Servikal yayma, Papanicolaou testi, Patoloji
Correspondence: Remzi ABALI

Department of Obstetrics and Gynaecology, Namık Kemal University, Faculty of Medicine, TEKİRDAĞ, TURKEY

E-mail: remziabali@yahoo.com Phone: +90 5327315360 


\section{INTRODUCTION}

Cervical cancer is the second most common cancer in females globally. It is possible to diagnose earlier and manage better compared to past years with the development of methods for early diagnosis and treatment. However, it continues to be an important cause of morbidity and mortality in women. There are approximately 500.000 new cases and 280.000 deaths every year and $83 \%$ of these cases are from developing countries, making up $15 \%$ of female cancers (1).

A significant decrease in the incidence and mortality of cervical cancer can be realized with effective cervical cytology screening programs (2). However, there is also an increase in the diagnosis of precancerous cervix lesions. The aim of the Papanicolaou (Pap) smear test is to detect precancerous cervix lesions before they become invasive cancer. The accuracy of the Pap smear test is evaluated using sensitivity, specificity and predictive value. Evaluating the correlation between cervical cytology and biopsy is the best method of determining the Pap smear test accuracy. However, it is not a perfect method due to the potential sampling and interpretation errors (3).

We retrospectively evaluated the correlation with histopathology results in patients who had been cytopathologically found to have squamous cell abnormality with the cervical smear method.

\section{MATERIAL AND METHOD}

The conventional Pap smears obtained from women presenting at the İstanbul Training and Research Hospital Department of Obstetrics and Gynecology between 2005 and 2008 were evaluated retrospectively. Patients with squamous cell abnormalities in the smear results were included in the study. Information related to the patients was obtained from the patient files, cytopathology and histopathology reports and patient follow-up forms.

The smears were taken with a CerviBrush ${ }^{\circ}$ and put on a slide. They were then fixed by using a spray from 25-30 $\mathrm{cm}$ and evaluated at our hospital's pathology laboratory. Conventional Pap smear results were classified according to the 2001 Bethesda system. A total of 374 patients with ASC-US (atypical squamous cells - unknown significance), ASC-H (atypical squamous cells where a high-grade lesion cannot be eliminated), LSIL (low-grade squamous intraepithelial lesion), HSIL (high-grade squamous intraepithelial lesion) or invasive carcinoma underwent colposcopic cervical biopsy after 4-6 weeks. Biopsy results were evaluated with the cervical intraepithelial neoplasm classification and the correlation with Pap smear results was investigated.

Biopsy results were divided into 4 groups as nonneoplastic (chronic cervicitis and inflammation-related regenerative changes), LSIL (CIN I/mild dysplasia), HSIL (CIN II and CIN III/moderate and severe dysplasia) and invasive carcinoma.

The SPSS (Statistical Package for the Social Sciences) software was used for statistical calculations. A p value $<0.05$ was considered significant for statistical evaluation. The Spearman correlation test, Tukey HSD for two-way comparisons, one-way variance analysis, the Tamhane test and anova test were used for statistical evaluations. Two-way comparisons were used to create $2 \times 2$ tables and calculate the positive predictive values.

\section{RESULTS}

A total of 374 patients were included in the study. The mean age was $45.15 \pm 10.78$ (range 23-78). The cases ages of the cytology categories were compared and the difference was found to be significant $(\mathrm{p}=0.001)$. A significant difference was found between the ages of ASC-US and invasive cancer cases $(p<0.02)$. There was also a significant difference between the ages of LSIL and HSIL patients $(p<0.02)$ (Table I).

Cytopathologically, there were 256 (68.4\%) ASC-US, 21 (5.6\%) ASC-H, 31 (8.2\%) LSIL, 48 (12.8\%) HSIL, 18 (4.8\%) invasive carcinoma cases.

We found a significant difference between the ages of the nonneoplastic group and CIN I patients $(\mathrm{p}=0.001)$. There was also a significant difference between the ages of CIN I and squamous cell carcinoma patients $(\mathrm{p}=0.002)$ (Table II)

Histopathologically, there were 213 (57\%) nonneoplastic lesions, 85 (22.7\%) CIN I cases, 14 (3.7\%) CIN II cases, 34 (9.0\%) CIN III cases, and 28 (7.5\%) invasive squamous cell carcinomas (Table III).

The relationship between cytopathological and histopathological results was significant $(r=0.58$, $\mathrm{p}=0.0001)$. When all the squamous cell abnormalities in the cervicovaginal cytology was included, the sensitivity of the smear test for CIN I and higher grade lesions was 56.95\% (213/374) while false positivity was 43.04\% (161/374). When ASC-US and ASC-H were excluded, the sensitivity was $77.31 \%$ (75/97) and false positivity $22.68 \%(22 / 97)$.

We were unable to calculate sensitivity, specificity and negative predictive value for the patient groups as there were no real negative or false negative groups. The correlation 
was calculated using the positive predictive values (PPV) according to our study data.

The cyto-histopathological correlation increased in parallel to the grade of PPV and was $100 \%, 62 \%$ and $38 \%$ for invasive carcinoma, HSIL and LSIL, respectively (Table IV).

The cyto-histopathological comparison for cervical intraepithelial lesions (CIN I-II-III) and invasive carcinoma revealed that the smear test predictive value increased as the epithelial abnormality of the lesion increased and was $30 \%$ for ASCUS, $48 \%$ for LSIL, $87 \%$ for HSIL and 59\% for HSIL+LSIL (Table V).

A cervical intraepithelial lesion (CIN II-III) was found in $3-5 \%$ of the total ASCUS cases. Comparison of the cervical

Table I: Distribution of mean ages of cases where a cytopathological epithelial cell abnormality was found

\begin{tabular}{|l|r|c|r|}
\hline Cytopathological diagnosis & \multicolumn{1}{c|}{$\mathbf{n}$} & Mean & \multicolumn{1}{c|}{ SD } \\
\hline ASC-US & 256 & 44.35 & 10.15 \\
\hline ASC-H & 21 & 45.05 & 9.23 \\
\hline LSIL & 31 & 41.68 & 10.68 \\
\hline HSIL & 48 & 48.80 & 11.83 \\
\hline Invasive carcinoma & 18 & 52.61 & 12.99 \\
\hline Total & 374 & 45.16 & 10.76 \\
\hline
\end{tabular}

invasive disease correlation of ASCUS and ASC-H cases showed a higher correlation value for ASC-H than ASCUS.

\section{DISCUSSION}

The aim of using the cervical smear test is screening sexually active women to enable early detection and treatment of precancerous lesions and prevent mortality due to cervical cancer. There is a relationship between the widespread use of the cervical smear test and decreased mortality due to invasive squamous cancer. Screening programs have therefore been developed all over the world. Cases where a cytological abnormality has been detected undergo biopsy from the suspect lesions under colposcopy for a definite diagnosis (4).

Table II: Distribution of mean ages of histopathological diagnostic groups

\begin{tabular}{|l|r|c|r|}
\hline Cervical Biopsy & \multicolumn{1}{c|}{ n } & Mean & \multicolumn{1}{c|}{ SD } \\
\hline Nonneoplastic & 213 & 45.78 & 9.36 \\
\hline CIN I & 85 & 40.14 & 10.66 \\
\hline CIN II & 14 & 46.73 & 9.19 \\
\hline CIN III & 34 & 47.52 & 12.04 \\
\hline Invasive Carcinoma & 28 & 51.21 & 12.45 \\
\hline Total & 374 & 45.21 & 10.76 \\
\hline
\end{tabular}

Table III: Histopathological evaluation results of cases where epithelial cell abnormalities were found

\begin{tabular}{|l|c|c|c|c|c|c|}
\hline $\begin{array}{l}\text { Cytopathological } \\
\text { Diagnosis }\end{array}$ & Nonneoplastic & CIN I & CIN II & CIN III & Invasive Carcinoma & TOTAL \\
\hline ASC-US & $179(47.8 \%)$ & $68(18.1 \%)$ & $6(1.6 \%)$ & $3(0.8 \%)$ & $0(0 \%)$ & $256(68.4 \%)$ \\
\hline ASC-H & $12(3.2 \%)$ & $3(0.8 \%)$ & $3(0.8 \%)$ & $3(0.8 \%)$ & $0(0 \%)$ & $21(5.6 \%)$ \\
\hline LSIL & $16(4.2 \%)$ & $12(3.2 \%)$ & $2(0.5 \%)$ & $1(0.2 \%)$ & $0(0 \%)$ & $31(8.2 \%)$ \\
\hline HSIL & $6(1.6 \%)$ & $2(0.5 \%)$ & $3(0.8 \%)$ & $27(7.2 \%)$ & $10(2.6 \%)$ & $48(12.8 \%)$ \\
\hline Invasive Carcinoma & $0(0 \%)$ & $0(0 \%)$ & $0(0.0 \%)$ & $0(0 \%)$ & $18(4.8 \%)$ & $18(4.8 \%)$ \\
\hline Total & $213(56.9 \%)$ & $85(22.7 \%)$ & $14(3.7 \%)$ & $34(9.0 \%)$ & $28(7.4 \%)$ & $374(100 \%)$ \\
\hline
\end{tabular}

Table IV: Positive Predictive Values of cyto-histopathological diagnoses

\begin{tabular}{|l|c|c|}
\hline $\begin{array}{l}\text { Cyytopathological } \\
\text { Diagnosis }\end{array}$ & $\begin{array}{c}\text { Histopathological } \\
\text { Diagnosis }\end{array}$ & PPV \\
\hline LSIL & CIN I & 0.38 \\
\hline HSIL & CIN II-III & 0.62 \\
\hline Invasive Carcinoma & Invasive Carcinoma & 1 \\
\hline
\end{tabular}

Table V: Positive Predictive Values of Cytology Groups

\begin{tabular}{|l|c|}
\hline Cytopathological Diagnosis & PPV \\
\hline ASC-US & 0.30 \\
\hline ASC-H & 0.42 \\
\hline LSIL & 0.48 \\
\hline HSIL & 0.87 \\
\hline HSIL+LSIL & 0.59 \\
\hline
\end{tabular}


It is recommended that screening should be started in developed countries as soon as the patient becomes sexually active. The screening interval varies between 1 and 5 years by country. Many associations in Turkey suggest sexually active women over the age of 18 to undergo a smear test once a year for the first 3 years and then to be repeated every 3-5 years if the first 3 tests are negative (5). Additional methods such as cervicography and HPV DNA typing are also used for diagnosis.

It is difficult to definitely establish PPV of the Pap smear test for preinvasive lesions. The literature figures are 50-90\% for sensitivity and $31-90 \%$ for specificity (6). The PPV is $17-89 \%$ for preinvasive or microinvasive lesions and almost $100 \%$ for squamous cell carcinoma (7-10). This wide range for sensitivity indicates that all abnormal smear results should be evaluated.

The February 1999 AHCPR (Agency for Health Care Policy and Research) report has stated that conventional Pap smear sensitivity is not as high as previously reported (11). The conventional Pap smear sensitivity was mentioned as $51 \%$ and the specificity as $98 \%$ in this report. It was also reported that cervical cytology detected high risk lesions more accurately when the threshold value was high while a low threshold value (LSIL/ASCUS) led to lower possibility of finding low-risk or high-risk dysplasia (11).

A study where the cyto-histopathological correlation of 283 cases was analyzed showed full match between the cytology and biopsy in $51 \%$ of the cases while this rate was $63.9 \%$ and $74.6 \%$ for low-grade and high-grade lesions, respectively. Cervical cytology sensitivity was $91.7 \%$ (12).

We found increased cyto-histopathological correlation with the cervical intraepithelial lesion as the degree of epithelial cell abnormality increased. The PPV was $30 \%$ for ASCUS, $48 \%$ for LSIL, $87 \%$ for HSIL, and 59\% for HSIL+LSIL. We evaluated the cervical cytology and biopsy correlation again after matching the Bethesda terminology counterpart of the smear results with the CIN terminology result of the biopsy results. The PPV again showed an increase with the lesion degree and was $38 \%, 62 \%$ and $100 \%$ for LSIL, HSIL and invasive carcinoma cases, respectively.

Cervical precancerous lesions can be detected approximately 10 years before they become cancerous with the Pap smear screening. Comparison of the ages of our patients revealed a significant difference between CIN I and invasive carcinoma. The mean age for the CIN I group was 40.14 while the squamous cell carcinoma group had a mean age of 51.21 with a difference of over 10 years. This indicates that a period where lesions can be detected and treated before they become cancerous exists.
The clinical results of patients diagnosed as ASC-US and ASC-H by cervical smear can show great variety, from clearly benign lesions to potentially serious lesions and it is therefore not possible to provide a definite classification. Various laboratories report a cervical intraepithelial lesion rate of $15-43 \%$ among ASC-US cases (13-15). We found nonneoplastic changes in 179 (69.9\%), CIN I in 68 (26.6\%), CIN II in 6 (2.3\%) and CIN III in 3 (1.2\%) ASC-UC cases. The total rate of cervical intraepithelial lesions among cases with an ASC-US smear result was 30\%. The 21 cases with an ASC-H diagnosis were diagnosed as nonneoplastic in 12 (57.1\%), CIN I in 3 (14.2\%), CIN II in 3 (14.2\%) and CIN III in 3 (14.2\%). The total rate of cervical intraepithelial lesion in ASC-H cases was $42.8 \%$. The higher CIN II and CIN III rates in cases reported as ASC-H indicates a need for closer follow-up of these patients.

The false positive cases' follow up in this study showed regenerative changes due to chronic cervicitis or inflammation. The mean age of cases having a smear performed was also quite high (mean age $=45.16$ ). The decreased estrogen in the postmenopausal period leads to larger squamous cell nuclei and smaller cytoplasm size (atrophy). The addition of inflammation-related regenerative changes to these aging-related physiological changes makes differentiation from neoplastic lesions difficult (16). This increases the rate of smears reported as ASC-US. Most cases at our hospital present symptoms related to menopause or an infection and there are almost no patients who had smear tests for screening.

Another reason for the false high positivity rate may be the lack of a specialized histopathologist in our hospital. Cytotechnicians evaluate the cervicovaginal smear test in developed countries such as the U.S.A. and a second evaluation is by a specialized cytopathologist is suggested if abnormal changes are noticed (16). Cervicovaginal smears are usually obtained from patients presenting at the hospital for infection or menopause in our country and almost all these preparations contain regenerative cytopathological changes. The most common finding in false positive cases is also regenerative changes and their evaluation therefore becomes more important. It is suggested that regenerative changes can be divided into typical and atypical and the atypical regeneration group in particular be added to the ASC-US group. (17). The low number of pathologists in our county also makes it difficult for cases presenting difficulties with the differentiation between ASCUS and regenerative lesion to be evaluated by a second pathologist.

Differentiation of regenerative changes from neoplastic lesions in the smear test requires taking a biopsy after 3 
positive results in cases where ASCUS is found. However, hospitals like ours where patient follow-up is not possible due to the low socioeconomic level of the patient population usually proceed to endo-ectocervical biopsy with colposcopy even after a single positive result. This leads to an increased false positivity rate.

Other studies have demonstrated a relatively low level of false positivity in university hospitals in our country (18). However the mean age of the patient population is lower and the socioeconomic level is higher in these studies. This leads to a lower rate of regenerative changes and atrophic cells that were seen in our study and created difficulties in the differential diagnosis with ASCUS. These hospitals also have specialized cytopathologists (18). It is possible for the specialized cytopathologist to review cases where there are diagnostic difficulties between ASCUS and regenerative change.

A study has found $79.09 \%$ cyto-histopathological correlation in cases with a positive diagnosis regarding epithelial abnormality and cervicitis and regenerative changes were the pathologies found most commonly in false positive cases (15). Another study on cyto-histopathological correlation found a false negativity rate of $5.3 \%$ and false positivity rate of $3.5 \%$. The most common cause of false negativity was sampling error (17).

In conclusion, increased degree of neoplasia in cervical lesions increases the correlation between Pap smear and biopsy. The high sensitivity of the Pap smear test for high-grade neoplastic lesions shows that it is an effective screening test for cervical cancer and precursor lesions if used at suitable intervals. However, the cervical smear test is still not used at adequate levels as a screening test in our country. Most cases undergoing the cervical smear test have presented at the hospital for menopause or infection. This increases the risk of false positivity. Our country therefore needs programs that will increase the use of the cervicovaginal smear test as a screening test and decrease the mean age of the screening group.

\section{REFERENCES}

1. Parkin DM, Bray F, Ferlay J, Pisani P: Global cancer statistics, 2002. CA Cancer J Clin 2005, 55:74-108

2. Sankaranarayanan R, Gaffikin L, Jacob M, Sellors J, Robles S: A critical assessment of screening methods for cervical neoplasia. Int J Gynaecol Obstet 2005, 89:4-12

3. Rohr LR: Quality assurance in gynecologic cytology. What is practical? Am J Clin Pathol 1990, 94:754-758
4. Wright TC Jr, Cox JT, Massad LS, Twiggs LB, Wilkinson EJ: ASCCP-Sponsored Consensus 2001 Consensus Guidelines for the management of women with cervical cytological abnormalities. JAMA 2002, 287:2120-2129

5. Fink DJ: Change in American Cancer Society Checkup Guidelines for detection of cervical cancer. CA Cancer J Clin 1988, $38: 127-128$

6. Uyar DS, Eltabbakh GH, Mount SL: Positive predictive value of liquid-based and conventional cervical Papanicolaou smears reported as malignant. Gynecol Oncol 2003, 89:227-232

7. Soost HJ, Lange HJ, Lehmacher W, Ruffing-Kullmann B: The validation of cervical cytology: sensitivity, specificity and predictive values. Acta Cytol 1991, 35:8-14

8. Johnson SJ, Wadehra V: How predictive is a cervical smear suggesting invasive squamous cell carcinoma? Cytopathology 2001, 12:144-150

9. Clark SB, Dawson AE: Invasive squamous-cell carcinoma in ThinPrep specimens: diagnostic clues in the cellular pattern. Diagn Cytopathol 2002, 26:1-4

10. Mitchell H, Medley G, Drake M: Quality control measures for cervical cytology laboratories. Acta Cytol 1988, 32:288-292

11. McCrory DC, Matchar DB, Bastian L, Datta S, Hasselblad V, Hickey J, Myers E, Nanda K: Evaluation of cervical cytology. Evid Rep Technol Assess (Summ) 1999, 5:1-6

12. Yeoh GP, Chan KW: The accuracy of Papanicolaou smear predictions: cytohistological correlation of 283 cases. Hong Kong Med J 1997, 3:373-376

13. Eltabbakh GH, Lipman JN, Mount SL, Morgan A: Significance of atypical squamous cells of undetermined significance on ThinPrep papanicolaou smears. Gynecol Oncol 2000, 79:44-49

14. Aydın F, Tuncer ZÇ, Kuzey GM, Başaran M: Servikovaginal sitoloji ile ASCUS ve AGUS tanısı alan olguların değerlendirilmesi. T Klin J Gynecol Obst 2002, 12:148-154

15. Kaufman RH: Atypical squamous cells of undetermined significance and low-grade squamous intraepithelial lesion: diagnostic criteria and management. Am J Obstet Gynecol 1996, 175:1120-1128

16. Colgan TJ, Woodhouse SL, Styer PE, Kennedy M, Davey DD: Reparative changes and the false-positive/false-negative Papanicolaou test: a study from the College of American Pathologists Interlaboratory Comparison Program in Cervicovaginal Cytology. Arch Pathol Lab Med 2001, 125: 134-140

17. Özkara SK, YıldızK: Servikovaginal smear tarama programımızın Bethesda-2001 ışı̆̆gnda beş yıllık retrospektif değerlendirmesi. (10 598 olguda, 110 sito-histopatolojik korelasyon). Patoloji Bült 2002, 19:119-124

18. Mete O, Yavuz E, Tuzlalı S, İlhan R, Özlük Y, Topuz S, İyibozkurt C, Íplikçi A: Retrospective study of 112 patients who had colposcopy-guided biopsy: Comparison of the cytology results with histology. Turk Patoloji Derg 2007, 23:33-37 